\title{
PDGFB Gene Fusion Positive
}

National Cancer Institute

\section{Source}

National Cancer Institute. PDGFB Gene Fusion Positive. NCI Thesaurus. Code C148116.

An indication that a PDGFB fusion gene has been detected in a sample. 